


\title{
IDENTIFICATION OF MELANOCORTIN 1 RECEPTOR (MC1R) GENE BASED ON COAT COLOR OF BALI COWS OF KUPANG BY USINGTHE PCR-RFLP METHOD
}

\author{
A. C. Tabun ${ }^{1}$, T. Hartatik ${ }^{2}$ and Sumadi ${ }^{2}$ \\ ${ }^{1}$ Kupang State Agicultural Polytechnic,Jl. AdisuciptoPenfui, Kupang NTT 1152 - Indonesia. \\ ${ }^{2}$ Faculty of Animal Science, Gadjah Mada University, \\ Jl Fauna 3, Bulaksumur, Yogyakarta 55281 - Indonesia \\ Corresponding E-mail: arnold.tabun@gmail.com
}

Received March 11, 2013; Accepted May 16, 2013

\begin{abstract}
ABSTRAK
Tujuan penelitian adalah untuk mengidentifikasi gen Melanocortin 1 Receptor (MC1R) pada Sapi Bali di Kupang-Nusa Tenggara. Sampel darah yang diambil sebanyak 46 ekor yang terdiri dari 17, 18 dan 8 ekor masing-masing betina yang berwarna merah bata, hitam dan putih, serta 3 ekor jantan. Indentifikasi gen dilakukan dengan menggunakan metode PCR-RFLP. Amplifikasi produk PCR gen MC1R pada Sapi Bali Kupang sebesar 296 bp. Hasil digesti dengan enzim MspI menghasilkan genotipe EE $(169,136$ bp) pada sapi Bali jantan, betina merah bata dan putih. Terdapat 2 genotipe EE $(169,136$ bp) dan Ee (296, 169, 136 bp) pada sapi Bali betina hitam. Frekuensi alel sapi Bali Kupang memiliki alel E sebesar 0,99 (99\%) dan alel e sebesar 0,01 (1\%). Sapi Bali Kupang memiliki gen MC1R yang bersifat monomorfik dan yang dapat digunakan sebagai penanda warna bulu.
\end{abstract}

Kata kunci : Melanocortin 1 Reseptor, sapi Bali betina, warna bulu, amplifikasi, monomorfik.

\begin{abstract}
The objective of this study was to identify the Melanocortin 1 Receptor (MC1R) gene in sorrel-, black- and white-Bali cows originated from Kupang-East Nusa Tenggara. Blood samples were taken from 46 cows consisted of of 17, 18 and 8 of sorrel, black and 8 heads, respectively, and 3 heads of bull. The PCR-RFLP method was performed to identify the gene. Amplification of PCR gene MC1R of Kupang's Bali Cattle (KBC) was 296 bp. The digestion by using MspI enzyme showed that there were EE genotype $(169,136$ bp) in Bali bull, sorrel and white cows. Two 2 genotypes, those were EE (169, $136 \mathrm{bp})$ and $\mathrm{Ee}(296,169,136 \mathrm{bp})$ were found in black Bali cow. The frequency of $\mathrm{E}$ alele of KBC was $0.99(99 \%)$ and e alele was $0.01(1 \%)$. MC1R gene in KBC was monomorphic and the it can be used as the marker of the coat color in the population.

Keywords: Melanocortin 1 Receptor, Bali cow, coat color, amplification, monomorphic
\end{abstract}

\section{INTRODUCTION}

Bali cattle (Bos sondaicus) is superior to others because of their adaptability to high temperature, high fertility rate, hight carcass percentage, low fat content meat and being able to eat low-quality feeds. Bali cattle have various characteristics in horns, sorrel coat color as calves and it turns into black in Bali bull, while it remains sorrel in Bali cows, white legs and back thighs and black back line (eel line). Bali cattle experience abnormal color distortion of the normal color as black (Injin), Albino and Poleng cattels. Handiwirawan and Subandriyo (2004) found that $17 \%$ of Bali cattle have color distortions.

The difference in the skin/coat colors of the cattle results from the pigment that is influenced by Melanocortin 1 Receptor (MC1R) genes expressed on melanosite surface. Garcia-Barron et. al. (2005) suggested that melanine was biopolimer polymorphous and multifunctional consisting of eumelanin (brown-black), pheomelanin (red-yellow), mixed melanin (eumelanin and pheomelanin) and neuromelanin. The role of the MC1R gene in the pigmentation process of the coat color of the Bali cattle could be indentified by making molecular analysis of 
Polymerase Chain Reaction (PCR) and Restriction Fragment Length Polymorphism (RFLP) method. Saiki et. al. (1988) stated that PCR reaction consists of three phases namely high temperatrue to DNA denaturation, low temperature for primer embedment to DNA template and intermediate in which Taq Polymerase develops sequence among the primer. Fragment number will increase because template set will be resulted from each of cycles (34 to 45 cycles). The RFLP is the difference in the DNA fragment number resulting from restriction enzyme treatment in the analyzed DNA samples. The difference in the DNA fragment size was caused by the difference in the endonuclease restriction enzyme cutting locus (Kocher, 1989).

MC1R fragments were amplified from bovine genomic DNA from various breeds (i.e., Holstein, Brahman, Simmental) using the MSHMOU primers, the fragments digested using MspI, gets of allele A was represented by 421-, 181-, 18- and 12-bp fragments and B was represented by 328-, 181-, 94-, 18-, and 12-bp fragments (Werth et. al., 1996). Li et. al. (2008) suggested that the amplication of the MC1R gene of black, white and red-white Chinese Holstein cattles could be amplified using the fragment length of 296 bp and digested using MspI enzyme gives three genotypes namely EE $(160 ; 136 \mathrm{bp})$, Ee (296; 160; $136 \mathrm{bp})$, ee (296 bp). The results of the digestion of the MC1R gene with the MspI enzyme of the brown Hanwoo cattle as compared to Angus cattle, spotted Hanwoo cattle and black Hanwoo cattle do not have any restriction fragment sites and the digestion of the MC1R gene with BfuAI enzyme of the spotted Hanwoo cattle gives the biggest fragments of 337 and 143 bp (Mohantry, 2008). The distribution of the $M C 1 R$ haplotypes among the three investigated breeds in Tianzhu yaks and Maiwa yaks, $E^{Y I}$ haplotype was predominant $(0.68$ and 0.75 , respectively), followed by haplotype $E^{Y 3}$ in Tianzhu animals $(0.21)$ or by haplotype $E^{Y 2}$ in Maiwa breed (0.22), whereas in Jiulong there was a relatively equal distribution of the three haplotypes.(Shi et. al., 2009).

Based on the coat color of Bali cattle originated from Kupang (KBC), the colors is vary because of the color pigmentation influenced by the Melanocortin 1 Receptor (MC1R) gene. The objective of the study was to identify Melanocortin 1 Receptor (MC1R) gene in the coat color of KBC based on Polimerase Chain Reaction (PCR) and Restriction Fragment Length
Polymorphism (RFLP)method.

\section{MATERIALS AND METHODS}

\section{Sampling and DNA Extraction}

The blood samples were collected from Bali cattle raised in the village of Parity and Oeteta Sulamu District, Kupang Regency. The total samples were 46 blood of cattle, in which consisted of 43 cows (17 Red-brown (sorrel), 18 black, 8 white) and three bulls. Blood samples were collected from the jugular vein by using a vacuntainer containing EDTA which was preserved under $-20^{\circ} \mathrm{C}$. DNA was extracted from blood samples by using standard SDS/proteinase K extraction (Sambrooket al, 1989). The analysis of DNA samples were conducted on the Laboratory of Animal Breeding, Faculty of Animal Science, Gadjah Mada University.

\section{Polymerase Chain Reaction (PCR)}

Amplification of MC1R gene was done using the primers forward: 5'GGACCCTGAGAGCAAGCAC-3' and reverse: 5'-CTCACCTTCAGGGATGGTCTA-3' with PCR product of $296 \mathrm{bp}$ (Li et al., 2008). Total reaction volume of $10 \mu \mathrm{l}$ of MC1R gene amplification consisted of $0.5 \mathrm{ml}$ DNA, PCR kit $5 \mathrm{ml}, 10$ pmol primer, and $3.5 \mathrm{ml} \mathrm{DDW}$. The cycling conditions as follows: $5 \mathrm{~min}$ at $95^{\circ} \mathrm{C}, 30$ cycles of $94^{\circ} \mathrm{C}$ for $30 \mathrm{~s}, 57^{\circ} \mathrm{C}$ annealing for $30 \mathrm{~s}$, and $72^{\circ} \mathrm{C}$ for $30 \mathrm{~s}$, with a final extension at $72^{\circ} \mathrm{C}$ for $10 \mathrm{~min}$ using Thermal Cycler machine. PCR products were examined by electrophoresis through $1 \%$ agarose gel.

\section{Restriction Fragment Length Polymorphism (RFLP)}

The PCR products were digested with restriction endonuclease $M s p I$. Total volume 12 $\mathrm{ml}$ reactionRFLP for MC1R gene were consist of $3 \mathrm{ml}$ of PCR product, $0.1 \mathrm{ml}$ MspI enzymes, 1.25 $\mathrm{ml}$ 10X buffer, and $7.7 \mathrm{ml}$ DDW. Then, incubation the mixtures at $37^{\circ} \mathrm{C}$ for 3 hours and the results of digestion was check by electrophoresis in $10 \%$ polyacrilamide gel for 3 hours.

\section{Data Analysis}

The results of the visualization of the DNA band were used in the calculation of genotype frequency and allele following the guideline of Pierce (2003).

a.. The genotype frequency of the MC1R genes on $\mathrm{KBC}$ (EE, Ee, ee) was calculated as 
follows:

Genotype frequency of EE $=($ Number of of EE individuals)/N

Genotype frequency of $\mathrm{Ee}=($ Number of of $\mathrm{Ee}$ individuals)/N

Genotype frequency of ee $=($ Number of of ee individuals) $/ \mathrm{N}$

b. The allele frequency. The frequency is the percentage or the proportion and always in the range of 0 to 1 . The allele frequency can be calculated as follows:

$$
\begin{aligned}
& \mathrm{P}=\mathrm{f}(\mathrm{E})=\frac{\left(2 \mathrm{n}_{\mathrm{EE}}+\mathrm{n}_{\mathrm{Ee}}\right)}{2 \mathrm{~N}} \\
& \mathrm{q}=f(e)=\frac{\left(2 n_{e e}+n_{E e}\right)}{2 N}
\end{aligned}
$$

where :

$\mathrm{n}_{\mathrm{EE}}, \mathrm{n}_{\mathrm{Ee}}$ and $\mathrm{n}_{\mathrm{ee}}=$ numbers of $\mathrm{EE}$, Ee and ee individuals

$\mathrm{N}=$ total number of individuals in the sample

\section{RESULTS AND DISCUSSION}

\section{PCR-RFLP}

MC1R gen fragment with 296 base pairing of KBC were amplified by PCR ( Figure 1). In the digestion by MspI enzyme of MC1R gene in $\mathrm{KBC}$ there were two types of restriction fragment : two bands with EE genotypes (160; $136 \mathrm{bp}$ ) and three bands with Ee genotypes (296; 160; 136 bp) (Figure 2).

Figure 2 illustrates the DNA fragment of the Bali bull, sorrel and white Bali cows containing two bands of the EE. Genotype (160; $136 \mathrm{bp}$ ). Meanwhile, the black Bali cow contained two bands of the genotype EE $(160 ; 136 \mathrm{bp})$ and three bands of the genotype Ee $(296 ; 160 ; 136 b p)$. The results showed that the sorrel-Bali cow, black Bali cow and Bali bulls have dominant extension genotype (EE). The genotype plays an important role in the coat color pigmentation of the Bali cattle. The pigmentation process of the $\mathrm{KBC}$ is influenced by the MC1R gene that important in the formation of the melanosite. The melanosite stimulates tyrosinase to produce eumelamine responsive to the colors of brown to black. Color pigmentation of the cattle is influenced by Melanocyte Stimulating Hormone Receptor (MSHr) and Melanocartin 1 Receptor (MC1R) genes. The Melanocyte Stimualting Hormone (MSH) plays an important role in determining the skin response to ultraviolete radiation and can influence the development of melanoma (Robbins et al., 1993; Klungland, 2001; Klungland and Vage, 2003; Sasaki et al., 2005; Schmutzand Barryere, 2007).

The MC1R gene can be activated by adrenal corticol hormone and Alfa-Melanocyte Stimulating Hormon (a-MSH) (Rouzaud et al., 2003 cit Li et al., 2008) and plays their role in causing the skin black color. The alfa-MSH hormone can not bind the MC1R gene because the presence of aguati influence can stimulate the synthesis of pheomelanin that causes the formation of red and yellow pigments. When $c A M P$ concentration in cell increases, it will activate nucleotide $\mathrm{C}$ and increases Tyrosinase synthesis, Eumelamin synthesis and Phaeomelanin synthesis and causes the formation of skin black color (Garcia-Borron et al., 2005). Furthermore, it is said that the melanin is polymorphous and multifunctional biopolymer including Eumelanin (black to brown), Pheomelanin (red to yellow), mixed color (the combination of Eumelanin and Pheomelanin) and Neuromelanin. The transformation of the nucleotide $\mathrm{T}$ into $\mathrm{C}$ in black Angus cows in the position $296 \mathrm{bp}$ produces black dominant allele responsible for black phenotype (Kungland et al., 1995). The molecule supports significant production of Eumelanin but there is not any transformation of the nucleotide $\mathrm{T}$ into $\mathrm{C}$ in Hanwoocattle that causes small number of Eumelamin in Angus cows (Mohantry et al., 2008).

The results of the study showed that white Bali cowsa were white in term of phenotype, but the results of PCR-RFLP MC1R gene indicated that the cows are black in term of genotype EE. It may due to the presence of metabolic disorder in the pigmentation process. It was stated by Rees (2003) that albinism is one of the archetypal inborn errors of metabolism described, with a frequency of around 1:20,000. The pheomelanin gives the red color, but it may be seen as orange or yellow at low concentration. If the pigment is not produced, white coat will occur (Hills, 2004). Mutations affecting the MC1R gene function determine coat color phenotypes in a large number of vertebrates, including livestock species such as cattle, sheep, goat, horse, pig, rabbit, and chicken. Some MC1R mutations induce Eumelanin production while others prompt Pheomelanin synthesis (Fantonesi et al., 2009).

Black Bali cow have three band though there was only one cattle with heterozygote (Ee). The heterozygote of black Bali cow may be caused by 


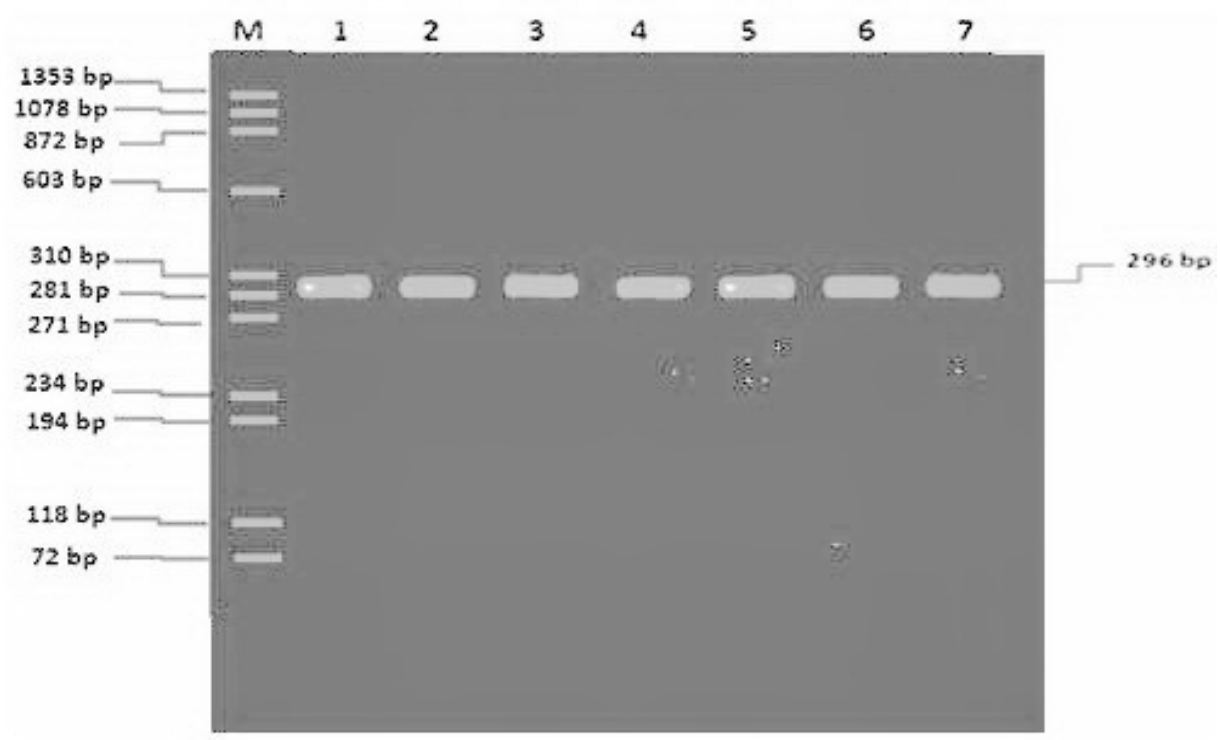

Figure 1. PCR product of the MC1R gene . Lane M: Marker ( $\Phi$ X174 DNA/BsuRI (HaeIII), PCR product (296 bp): Lane 1 (Bali bull), Lane 2.3 (Sorrel Bali Cow), Lane 4.5 (White Bali Cow) and Lane 6.7 (Black Bali Cow)

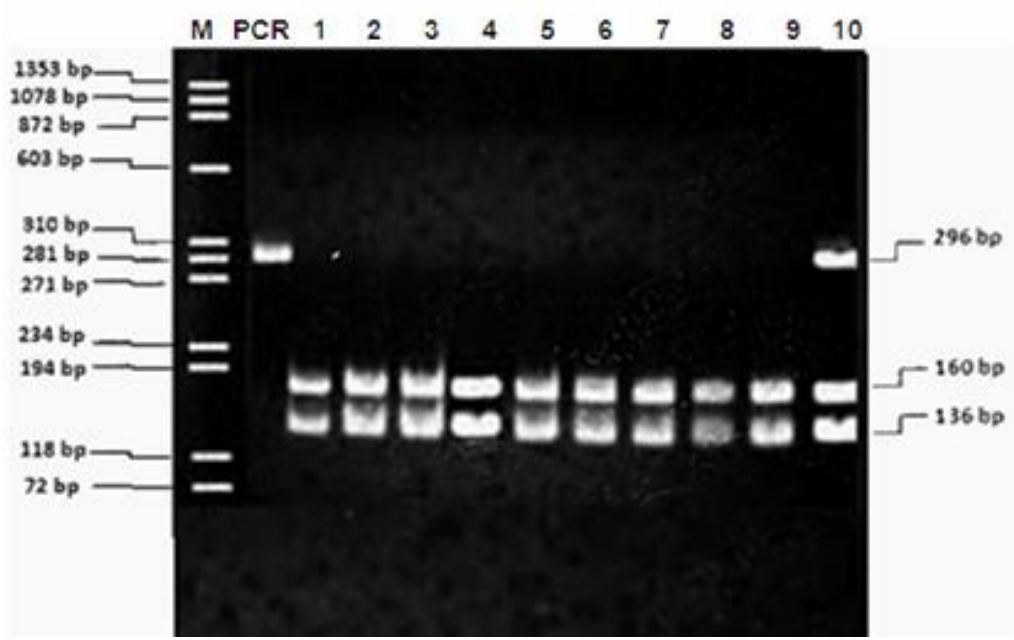

Figure 2. Visualisation of digestion with MspI enzymeof MC1R gen. Lane PCR: PCR product (296 bp). Lane M: Marker (ФX174 DNA/BsuRI (HaeIII), Lane 1,2 (Bali Bull); Lane 3,4,5 (Sorrel Bali Cow); Lane 6,7 (White Bali Cow); Lane 8,9 (Black Bali Cow), Lane 10 (Black Bali Cow)

mating, mutation and migration. The gene mutation is chemical change of one or some basa pairs in a single gene that causes the change in individual characteristics without any change in the number and the structure of its chromosome. The natural mating system without any exact identification of the bull is still common place.
Such mating took place between the animal of different families but still in the same order. Noor (2000) suggests that heterozygositosis is the parameter to measure genetic diversity in a population based on proportion per locus. The heterozygosity takes place because of outbreeding that depends on the genetic difference of their 
Table 1. Genotype and Allele Frequencies of MC1R Gene

\begin{tabular}{|c|c|c|c|c|c|c|c|c|c|}
\hline \multirow{2}{*}{ Bali cattle types } & \multirow{2}{*}{$\mathrm{n}$} & \multicolumn{3}{|c|}{ Genotype } & \multicolumn{3}{|c|}{ Genotype frequency } & \multicolumn{2}{|c|}{ Allele frequency } \\
\hline & & EE & $\mathrm{Ee}$ & ee & $\mathrm{EE}$ & $\mathrm{Ee}$ & ee & E & e \\
\hline Bali Bull (control) & 3 & 3 & - & - & 1.00 & - & - & 1.00 & - \\
\hline Sorrel Bali cow & 17 & 17 & - & - & 1.00 & - & - & 1.00 & - \\
\hline Black Bali cow & 18 & 17 & 1 & - & 0.94 & 0.06 & - & 0.97 & 0.03 \\
\hline White Bali cow & 8 & 8 & - & - & 1 & - & - & 1.00 & - \\
\hline Total & 46 & 45 & 1 & & & & & & \\
\hline Average & & & & & & & & 0.99 & 0.01 \\
\hline
\end{tabular}

predecessors. The outbreeding influences the increase in the heterozygote gene proportion (i.e., individuals with two different genes/allele) and decreases homozygote gene proportion (i.e., individuals whose genotype has the same two genes/allele).

\section{Genotype and Allele Frequency}

Genotype and allele frequencies of MC1R gene in $\mathrm{KBC}$ are presented in Table 1. The genotype frequency of Bali bull, cows with sorrel and white colors were dominant homozygote genotype $(\mathrm{EE}=1)$, while the black Bali cows had the genotype frequency of $\mathrm{EE}$ and Ee were 0.94 and 0.06 , respectively. The frequency of $\mathrm{E}$ allele $=1$ in Bali bull, black Bali cows had the frequency of the $\mathrm{E}$ allele $=0.97$ and the e allele $=0.03$. The mean frequency of the allele $\mathrm{E}$ of $\mathrm{KBC}$ was 0.99 and the e allele was 0.01 . The results showed that $\mathrm{KBC}$ in the study was monomorphic proved by 99\% of homozygote proportion. It is parallel with Harris (1994) statement that the homozygote locus proportion is more than $0.99(99 \%)$ was monomorphic.

The monomorphic found in $\mathrm{KBC}$ was due to inbreeding. It is clearly observed that the cattle reared extensively and semi-extensively and the mating taken place in grazing fields without any control by the farmer. It is consistent with Baker and Manwell (1986) explaining that the factors influencing the high heterozygote are overdomination (positive heterosis), the difference in gene frequency between bull and cow, mating was not selected (assortative mating), while the factors influencing the low heterozygosity was negative heterosis (repressive genes) and close family mating (inbreeding). The inbreeding can increase homozygote of genes and decrease heterozygosity proportion. The farther family relationships between the two animals, the less their genes in common, and the greater level heterosigousity (Noor, 2000).

\section{CONCLUSION}

Bali Cattle originated from Kupang had monomorphic Melanocortin 1 Receptor (MC1R) genes. MC1R genes can be used as the coat color marker.

\section{ACKNOWLEDGEMENTS}

The author expresses sincere gratitude to DIKTI that have supported in financing the study through BPPS scholarship of 2011 and to all of the farmers in Pariti and Oeteta villages, Sulamu district, Kupang regency who have provided their cattle and taking blood samples.

\section{REFERENCES}

Baker, A.C.M and C. Manwell. 1986. Population Genetics, Molecular Marker and Gene Conservation of Bovine Breeds. In : Neimann and Hickman (Ed). World Animal Science. Elsevier Healt Sciences. London.

Fontanesi, L., F, Beretti, V. Riggio, S. Dall'Olio, E. G. González, R. Finocchiaro, R. Davoli, V. Russo and B. Portolano. 2009. Missense and nonsense mutations in melanocortin 1 receptor (MC1R) gene of different goat breeds: association with red and black coat colour phenotypes but with unexpected 
evidences. BMC Genetics. $8: 1016$ - 1021.

Garcia-Borron, J.C., B.L.Sanchez-Laorden and C. Jimenez-Cervantes. 2005. Melanocortin-1 receptor structure and functional regulation. Department of Biochemistry and Molecular Biology, School of Medicine, University of Murcia, Murcia, Spain. Pigment cell Ress. 8: 393-410.

Handiwirawan, E and Subandriyo. 2004. Potential diversity of Bali cattle genetic resources. Wartazoa. 14 (3):107-115.

Harris, H. 1994. Biochemical fundamentals of Human Genetics. Third edition. Gadjah Mada University Press. Yogyakarta.

Hillis, D.M. 2004. The Genetics Of Coloration In Texas Longhorns : The Basic Colors. Edisi I. Artikel Publishire. Texas Longhorn trails.16 (3):40 - 41.

Klungland, H. 2001. Coat colour genetics in cattle. Plant and Animal Genome IX Conference. Town \& Country Hotel, San Diego, C.A.

Klungland, H. and D.I. Vage. 2003. Pigmentary switches in domestic animal species. Annals of the New York Academy of Sciences. 994: 331-338.

Klungland, H., D.I. Vage, L. Gomez-Raya, S. Adalsteinson and S. Lien. 1995. The role of melanocyte-stimulating hormone (MSH) receptor in bovine coat color determination. Mammalian Genome. 6:636-639.

Kocher, T.D., W.K. Thomas, A. Meyer, S.V. Edwards, S. Paabo, F.X. Villablanca and A.C. Wilson. 1989. Dynamics of mitochondrial DNA evolution in animals: Amplification and sequencing with conserved primers. Proc. Natl. Acad. Sci. USA: 86 6196-6200.

Li, Qiu-ling., L. Jian-bin, Z. Zheng-feng, W. Hong-mei, W. Chang-fa, G. Yun-dong., H. Ming-hai and Z. Ji-feng. 2008. Study on red coat color gene and prediction of the secondary structure in Chinese Holstein. Agricultural Sciences in China. 7(8):10161021.

Mohanty, T.R., K.S. Seo, K.M. Park, T.J. Choi, H.S. Choe, D.H. Baik and I.H. Hwang. 2008. Molecular variation in pigmentation genes contributing to coat colour in native Korean Hanwoo cattle. Journal compilation. International Society for Animal Genetics.
39: 550-553.

Noor, R.R., Muladno, B. Benjamin, Z. Hedah, and Herliantin. 2000. Purity Test Bali Cattle through Protein, Microsatellite DNA, Coat and Chromosome Structure. Research reports. Faculty of Animal Science and Artificial Insemination Center Singosari. Bogor.

Pierce, B. A. 2003. Genetics: A Conceptual Approach. Fourth Edition. W. H. Freeman and Company. New York: 695-700.

Rees, J.L. 2003. Geneticsof Hair and Skin Color. Annu.Rev.Genet. 37:67-90.

Robbins, L.S., J.H. Nadeau., K.R. Johnson, M.A. Kelly, L. Roselli-Rehfuss, E. Baack, K. G. Mountjoy, and R. D. Cone. 1993. Pigmentation phenotypes of variant extension locus alleles result from point mutations that alter MSH receptor function. Cell. 72:827-834.

Saiki, R.K., D.H. Gelfand, S. Stoffel, S. Schart, R. Higushi, G.T. Horn, K.B. Mullis, and H.A. Erlich. 1988. Primer-Direction Enzymatic Amplification of DNA with a Thermostable DNA Polymerase. Science. 239:487- 491.

Sambrook, J., E.F. Fritsch and T. Maniatis. (1989). Molecular Cloning: A Laboratory Manual, 2nd edn. Cold Spring Harbor Laboratory Press, New York, NY.

Sasaki, S.M., U.H. Mannen., C. Hiura and S. Tsuju. 2005. Allel frequencies of extension locus encoding the melanocortin-1 reseptor in japanese and korean cattle. J. Anim Sci: 76(2):129-132.

Schmutz, S.M and T.G. Barryere. 2007. The genetics of cream coat color in dogs. J. Hered. 98 (5) : 544-548.

Shi, Y. C., Yi Huang, Qing Zhu, L. Fontanesi, Yong-Gang Yao and Yi-Ping Liu. 2009. Sequence Characterization of the MC1R Gene in Yak (Poephagus grunniens) breeds with different coat colors. Journal of Biomedicine and Biotechnology. Published online June 29, 2009. doi:10.1155:861046.

Werth, L.A., G.A. Hawkins, A. Eggen, E. Petit, C. Elduque, B. Kreigesmann and M.D. Bishop. 1996. Rapid Communication: Melanocyte Stimulating Hormone Receptor (MC1R) maps to bovine chromosome 18. J. Anim Sci. 74:262. 